\title{
Cellular and molecular responses to acute cocaine treatment in neuronal-like N2a cells: potential mechanism for its resistance in cell death
}

\author{
Ramesh B. Badisa', Sungsool Wi' ${ }^{2}$ Zachary Jones ${ }^{3}$, Elizabeth Mazzio' ${ }^{1}$ Yi Zhou ${ }^{3}$, Jens T. Rosenberg ${ }^{2}$, Lekan M. Latinwo ${ }^{4}$,
} Samuel C. Grant ${ }^{2}$ and Carl B. Goodman ${ }^{1}$

\begin{abstract}
Cocaine is a highly abused drug that causes psychiatric and neurological problems. Its entry into neurons could alter cell-biochemistry and contribute in the manifestation of early pathological symptoms. We have previously shown the acute cocaine effects in rat C6 astroglia-like cells and found that these cells were highly sensitive to cocaine in terms of manifesting certain pathologies known to underlie psychological disorders. The present study was aimed to discern acute cocaine effects on the early onset of various changes in Neuro-2a (N2a) cells. Whole-cell patch-clamp recording of differentiated cells displayed the functional voltage-gated $\mathrm{Na}^{+}$and $\mathrm{K}^{+}$channels, which demonstrated the neuronal characteristics of the cells. Treatment of these cells with acute cocaine $(1 \mathrm{~h})$ at in vivo (nM to $\mu M)$ and in vitro (mM) concentrations revealed that the cells remained almost 100\% viable. Cocaine administration at $6.25 \mu \mathrm{M}$ or $4 \mathrm{mM}$ doses significantly reduced the inward currents but had no significant effect on outward currents, indicating the $\mathrm{Na}^{+}$ channel-blocking activity of cocaine. While no morphological change was observed at in vivo doses, treatment at in vitro doses altered the morphology, damaged the neurites, and induced cytoplasmic vacuoles; furthermore, general mitochondrial activity and membrane potential were significantly decreased. Mitochondrial dysfunction enabled the cells switch to anaerobic glycolysis, evidenced by dose-dependent increases in lactate and $\mathrm{H}_{2} \mathrm{~S}$, resulting unaltered ATP level in the cells. Further investigation on the mechanism of action unfolded that the cell's resistance to cocaine was through the activation of nuclear factor E2-related factor-2 (Nrf-2) gene and subsequent increase of antioxidants (glutathione [GSH], catalase and GSH peroxidase [GPx]). The data clearly indicate that the cells employed a detoxifying strategy against cocaine. On a broader perspective, we envision that extrapolating the knowledge of neuronal resistance to central nervous system (CNS) diseases could delay their onset or progression.
\end{abstract}

\section{Introduction}

The abuse of pharmacological substances in modern society has increased exponentially during the last decade

\footnotetext{
Correspondence: Ramesh B. Badisa (badisa66@gmail.com)

${ }^{1}$ College of Pharmacy and Pharmaceutical Sciences, Florida A\&M University,

Tallahassee, FL 32307, USA

${ }^{2}$ The National High Magnetic Field Laboratory, Florida State University,

Tallahassee, FL 32310, USA

Full list of author information is available at the end of the article.

Edited by R. Killick
}

and has led to burgeoning psychiatric problems worldwide $^{1}$. Cocaine is one of the widely abused drugs that rapidly crosses the blood brain barrier and binds to various plasma membrane transporters on neurons. Even though cocaine is degraded rapidly from the body as evidenced by its short half-life ${ }^{2-4}$, its brief stay in the CNS sets off profound psychostimulatory impact on its users. In addition, cocaine also exerts toxic effects in different CNS cells, such as astrocytes, under in vivo and in vitro

\section{(c) The Author(s) 2018}

(c) (i) Open Access This article is licensed under a Creative Commons Attribution 4.0 International License, which permits use, sharing, adaptation, distribution and reproduction c. in any medium or format, as long as you give appropriate credit to the original author(s) and the source, provide a link to the Creative Commons license, and indicate if changes were made. The images or other third party material in this article are included in the article's Creative Commons license, unless indicated otherwise in a credit line to the material. If material is not included in the article's Creative Commons license and your intended use is not permitted by statutory regulation or exceeds the permitted use, you will need to obtain permission directly from the copyright holder. To view a copy of this license, visit http://creativecommons.org/licenses/by/4.0/. 
situations with regards to altering the morphology or cell size $^{5}$ or manifesting certain pathology underlying psychological disorders ${ }^{6}$. So far, there is no clear understanding on how cocaine exerts cytotoxicity in neurons.

Autophagy $^{7}$ and oxidative stress arising from dopamine degradation at the synaptic cleft ${ }^{8}$ have been cited as the common causes of death. Owing to cocaine's rapid degradation and clearance from the $\mathrm{CNS}^{2-4}$, and reversible nature of autophagy ${ }^{6,9}$, the role of autophagy in neuronal toxicity still remained unclear. Cocaine administration at $50-450 \mathrm{mg} / \mathrm{kg} /$ day in animal models neither caused cell death nor induced neurodegenerative changes $^{10,11}$ which raised doubt on the role of oxidative stress in neuronal death. Consistent with these reports, in vitro studies in mouse neuro-2a (N2a) cells treated with milli molar doses of cocaine also did not show cell death (unpublished results). In case of humans, post-mortem examination of several long-term cocaine users revealed only a $16 \%$ neuronal loss in the striatum and mid-brain ${ }^{12}$.

Compared to the long-term cocaine abuse ${ }^{12}$, a mere $16 \%$ neuronal loss, though significant, is not considered drastic, and highly bewildering given the perception that in vivo neurons are highly sensitive to cocaine-induced oxidative stress arising from dopamine degradation ${ }^{8}$. Although age, gender, esterase levels, and genetics are known contributing factors that may control neuronal damage in the brain, absence of drastic neuronal destruction in the long-term cocaine users ${ }^{12}$ or failure of neuronal casualty in animal studies ${ }^{10,11}$ may thereby imply the presence of some unknown factors resisting cocaine detrimental effect in the CNS. Lack of severe neuronal loss as a common denominator under in vivo ${ }^{10-12}$ and in our in vitro study is neither a co-incident nor a farfetched idea but may denote a similar underlying mechanism of neuronal resistance that warrants further investigation. In addition, identification of biochemical changes in cells with cocaine exposure is also important to determine its disruptive affects-a criterion in translational research.

It is not yet known what biochemical changes would cocaine induce in neurons; nor is clear how the change in neuronal biochemistry could lead in the development of resistance to cocaine. We hypothesized that identification of early response-changes with cocaine treatment would reveal the sub-cellular targets in neurons, and this identification would provide mechanistic insights underlying the cellular resistance to cocaine. The early responses we focused include change in gross cell morphology, cell viability (at in vivo and in vitro concentrations), vacuolation, cytotoxic markers that compromise cell membrane integrity (lactate dehydrogenase $[\mathrm{LDH}]$, reactive oxygen species [ROS], and lipid peroxidation), biochemical markers (general mitochondrial activity, its membrane potential, lactate, hydrogen sulfide $\left[\mathrm{H}_{2} \mathrm{~S}\right]$ ), and ATP levels. Finally, we investigated the genes responsible for cellular resistance to acute cocaine treatment and measured the levels of antioxidants (GSH, catalase and GPx) in the cells. Understanding the mechanism of neuronal resistance may carry significance in the field of neuroscience because it could help identifying the neuroprotective factor/s responsible for resistance and explore its application to several CNS diseases in terms of delaying their onset or progression.

\section{Results \\ Effect of cocaine at in vivo and in vitro doses}

After confirming the neuronal-like characteristics of N2a cells (Supplementary Figures S1, 2), we next assessed the effect of cocaine on neurite-connections and cell viability at pharmacologically relevant in vivo doses, which usually range from nano to lower micro molar in drug addicts ${ }^{13}$. Under our test conditions, none of the doses treated for $1 \mathrm{~h}(1,5,10,25$, and $50 \mathrm{nM}$; and 0.1, 0.2, $0.5,1,5$, and $6.25 \mu \mathrm{M})$ induced any type of changes in the cells. Even at $6.25 \mu \mathrm{M}$ treatment, the cells appeared as the controls with well-preserved neurites and inter-neuronal connections (Fig. 1, arrows in $6.25 \mu \mathrm{M}$ ). Similarly, there was no loss $(n=8, P>0.05)$ in cell viability at any of these doses compared to the control (Supplementary Figure S3A). This warranted increasing of cocaine to milli molar concentrations based on previous reports ${ }^{14-16}$.

Alteration in cell morphology is one of the earliest signs of toxicity; so we initially evaluated the effect of 2,3 and 4 $\mathrm{mM}$ cocaine on cell morphology. While control cells displayed triangular or polygonal morphology (Fig. 2, red arrows), cocaine treatment at $2-4 \mathrm{mM}$ significantly altered the morphology to round (Fig. 2, red arrows in $4 \mathrm{mM}$ treatment). Furthermore compared to the control, neurite structures were damaged with treatment, causing loss in the inter-neuronal connections (Fig. 2, black arrows in $4 \mathrm{mM}$ ); yet, there was no change in cell viability at any treatment (Supplementary Figure S3B; $n=12, P>$ 0.05). However, cytoplasmic vacuoles were observed (Fig. 3) in a dose-dependent manner (Supplementary Figure S3C; $\left.n=12, F_{(3,44)}=9.49, P<0.05\right)$ in cocainetreated cells compared to the control. Vacuolation with cocaine treatment was also observed earlier in rat C6 astroglia-like cells; ${ }^{6}$ however, unlike N2a neuronal-like cells, cocaine cytotoxicity was more pronounced in C6 astroglia-like cells; ${ }^{6}$ similarly, the morphological alterations were more rapid in these cells ${ }^{6}$ compared to the $\mathrm{N} 2 \mathrm{a}$ neuronal-like cells. Videography in the present study indicated that the morphological changes began manifesting after about $30 \mathrm{~s}$ of cocaine treatment $(3 \mathrm{mM})$ in rat C6 astroglia-like cells followed by a type of movement -referred as "retractory movement". At the end of the movement, the cells were seen clumped in the form of separate islands (Supplementary Video 1). Interestingly, $\mathrm{N} 2$ a neuronal-like cells treated with $3 \mathrm{mM}$ cocaine did not 


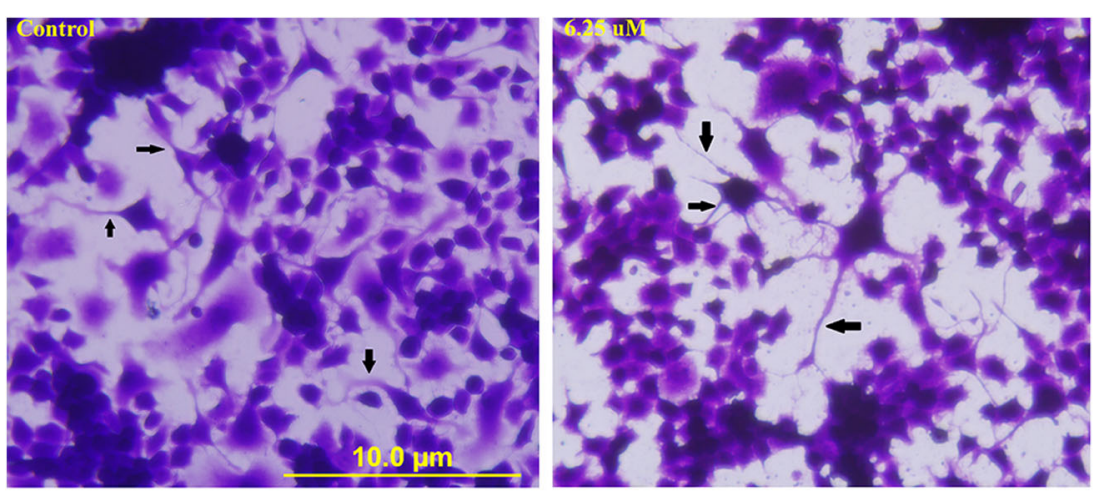

Fig. 1 Effect of in vivo concentration of cocaine on morphology. The cells were treated with equal volume of vehicle (PBS control) or $6.25 \mu \mathrm{M}$ cocaine for $1 \mathrm{~h}$. Morphological images were taken using an inverted phase contrast IX-70 Olympus microscope with $\times 20$ objective. Arrows show the inter-neuronal connections in the control and $6.25 \mu \mathrm{M}$ treated cells. Scale bar: $10 \mu \mathrm{m}$

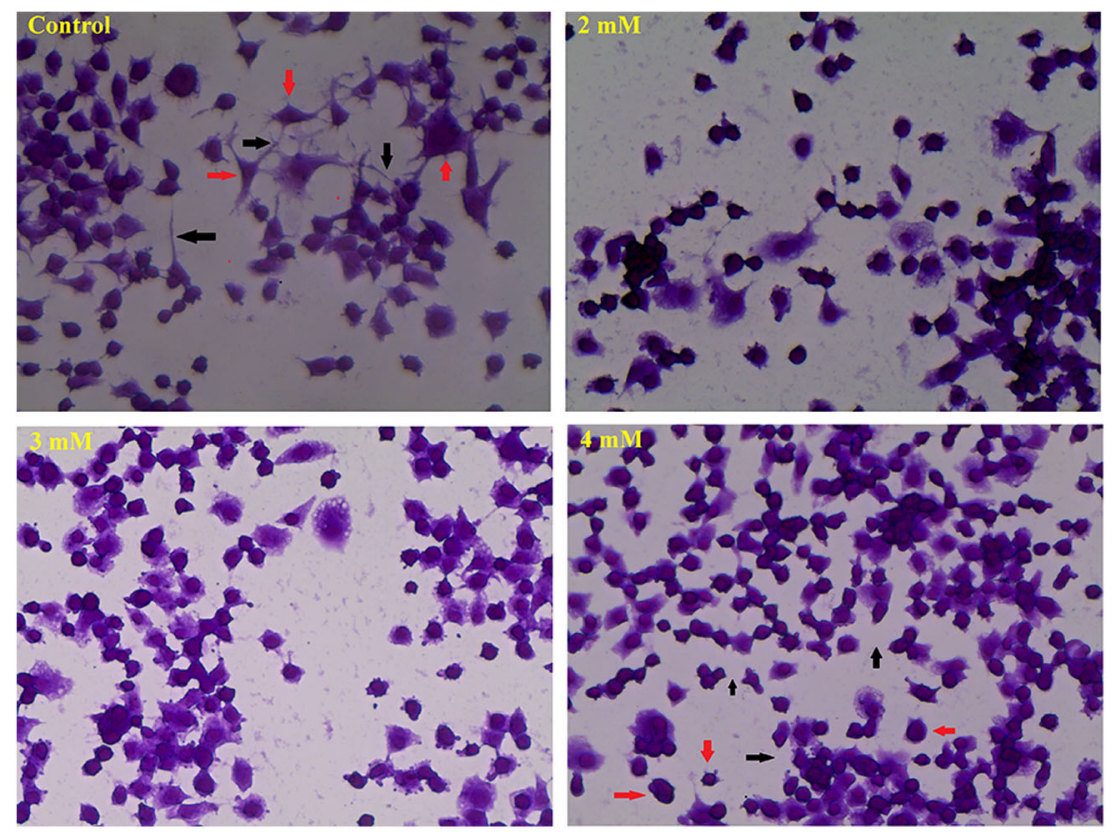

Fig. 2 Effect of in vitro doses of cocaine on cell morphology. The cells were treated with equal volume of vehicle (PBS control) or 2-4 mM cocaine for $1 \mathrm{~h}$. Morphological images were taken using EVOS Cell Imaging Systems with $\times 40$ objective. Black arrows show the inter-neuronal connections in the control cells and their loss with $4 \mathrm{mM}$ treatment; red arrows indicate triangular or polygonal morphology of control cells but changed to round upon $4 \mathrm{mM}$ treatment.

exhibit the retractory movement (Supplementary Video 2) even up to 5 min of videography. Although the mechanism for "retractory movement" observed in C6 astroglialike cells is not known, nor investigated currently, it is possible that actin filaments of the cytoskeleton ${ }^{6}$ and calcium ions are involved. The aim of these videos is only to complement the resistant nature of $\mathrm{N} 2 \mathrm{a}$ neuronal-like cells to cocaine treatment compared to $\mathrm{C} 6$ astroglia-like cells ${ }^{6}$ in terms of retractory movement.

Despite treatment of N2a neuronal-like cells with milli molar doses of cocaine, there was neither LDH release to denote membrane damage (Fig. $4 \mathrm{a}, n=8 ; P>0.05$ ) nor ROS generation (Fig. 4b; $n=8, P>0.05$ ) or lipid peroxidation (Fig. 4c; $n=12, P>0.05$ ), suggesting their noninvolvement in the altered cell morphology.

\section{Inhibition of sodium channel activity}

To examine the effects of cocaine on electrophysiology, the cells were submerged in low $(6.25 \mu \mathrm{M})$ or high $(4 \mathrm{mM})$ doses of cocaine in extracellular recording solution prior to whole-cell patch-clamp recording. Cocaine treatment significantly reduced inward currents at both low (Fig. 5a) 


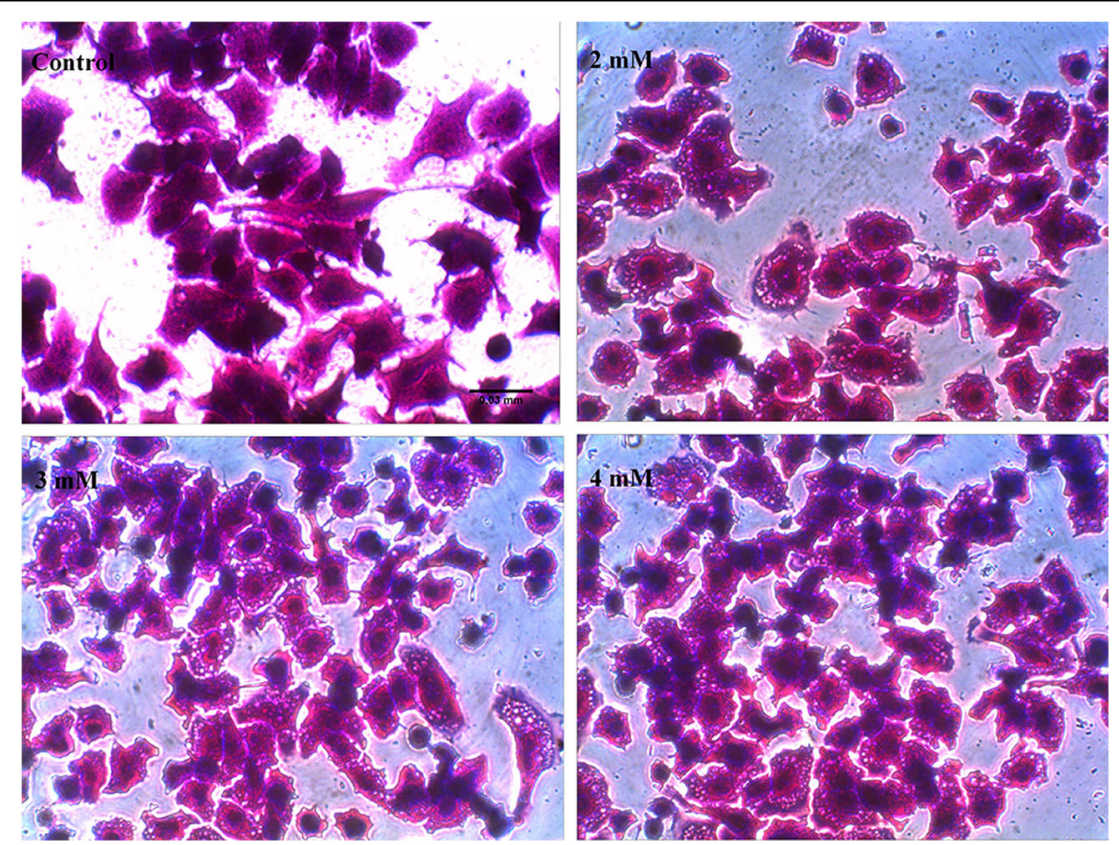

Fig. 3 Induction of vacuoles in cells at in vitro doses of cocaine. The cells were treated with equal volume of vehicle (PBS control) or 2-4 mM cocaine for $1 \mathrm{~h}$. Optical images of vacuoles were taken using an inverted phase contrast IX-70 Olympus microscope with $\times 40$ objective. Scale bar: $0.03 \mathrm{~mm}$

and high (Fig. $5 \mathrm{~b})$ doses $\left(n=8, F_{(2,21)}=21.81, P<0.001\right)$ and had no significant effect on outward currents (Fig. 5c). The peak inward current amplitude at $-15 \mathrm{mV}$ was $-238.37 \pm 48.29 \mathrm{pA}$ in untreated cells compared to $-19.26 \pm 9.61 \mathrm{pA}$ in low cocaine dose and $1.61 \pm$ $2.55 \mathrm{pA}$ in high cocaine dose. This result is consistent with the known $\mathrm{Na}^{+}$channel-blocking activity of cocaine in excitable cells ${ }^{17,18}$. No differences were observed between untreated and cocaine-treated cells in spike activity or spontaneous postsynaptic current activity (Supplementary Figure S4).

\section{Mitochondrial dysfunction}

The mitochondrial enzymes reduce the tetrazolium compound of MTS into a pink formazan ${ }^{19}$. Thus, measurement of total formazan in cells reflects the general metabolic status of mitochondria. In our study, cells treated with cocaine at $2-4 \mathrm{mM}$ for $1 \mathrm{~h}$ showed a small but significant $\left(n=12, F_{(3,44)}=12.17, P<0.05\right)$ decrease in the general metabolic activity of mitochondria compared to the control (Fig. 6a). The decrease was ( \pm standard error of the mean (SEM)) $97.4 \pm 0.7,94.5 \pm 1.2$, and $88.6 \pm 2.4 \%$ of the control value $(100 \%)$ at 2,3 , and $4 \mathrm{mM}$ cocaine, respectively. Similarly, there was a significant $\left(n=8, F_{(3,28)}=16.46, P<0.05\right)$ dose-dependent decrease in membrane potential compared to the control (Fig. 6b). The average decrease $( \pm$ SEM) at 2,3 and $4 \mathrm{mM}$ cocaine was $90.0 \pm 2.6,79.1 \pm 2.3,80.4 \pm 3.2 \%$, respectively compared to the control (100\%).

\section{Anaerobic features}

Loss in mitochondrial function switches the cells to anaerobic respiration as a means of survival. We evaluated the anaerobic characteristics by measuring the levels of lactate, and $\mathrm{H}_{2} \mathrm{~S}$. Exposure of N2a neuronal-like cells to cocaine at increasing concentrations $(2,3$, and $4 \mathrm{mM})$ for $1 \mathrm{~h}$ significantly $\left(n=12, F_{(3,43)}=21.04, P=0.0001\right)$ and dose-dependently increased lactate release into the medium compared to the control cells (Fig. 7a). The increase $( \pm$ SEM) was $111.7 \pm 3.1 \%$ and $118.4 \pm 3.9 \%$ compared to the control (100\%) at 3 and $4 \mathrm{mM}$ cocaine, respectively. Cocaine at $2 \mathrm{mM}$ or less did not induce significant lactate release in the medium. In order to further confirm the release of lactate, the study was repeated with $2-4 \mathrm{mM}$ cocaine treatments and the media were analyzed by ${ }^{1} \mathrm{H}^{+}$ NMR spectroscopy. After suppressing the dominant water peak at $4.8 \mathrm{ppm}$ in the spectrum by applying WATERGATE pulse sequence ${ }^{20}$, the relevant frequency range (0-4.7 ppm) of each spectrum was shown (Fig. 7b). Lactate peaks were visible at $1.25 \mathrm{ppm}$ for the methyl group (doublet) and 4.04 ppm for the methine group (quartet). Since there was no cocaine peak detected in the experimental blank, it is obvious that approximately a 3 -fold increase in lactate compared to the control cells (Fig. 7b) was due to cocaine treatment alone.

We next tested whether cocaine treatment could release $\mathrm{H}_{2} \mathrm{~S}$, a biomarker of anaerobic metabolism, from the cells. The data indicated that there was a small but significant $\left(n=16, F_{(3,84)}=3.57, P<0.05\right)$ increase in $\mathrm{H}_{2} \mathrm{~S}$ release in 

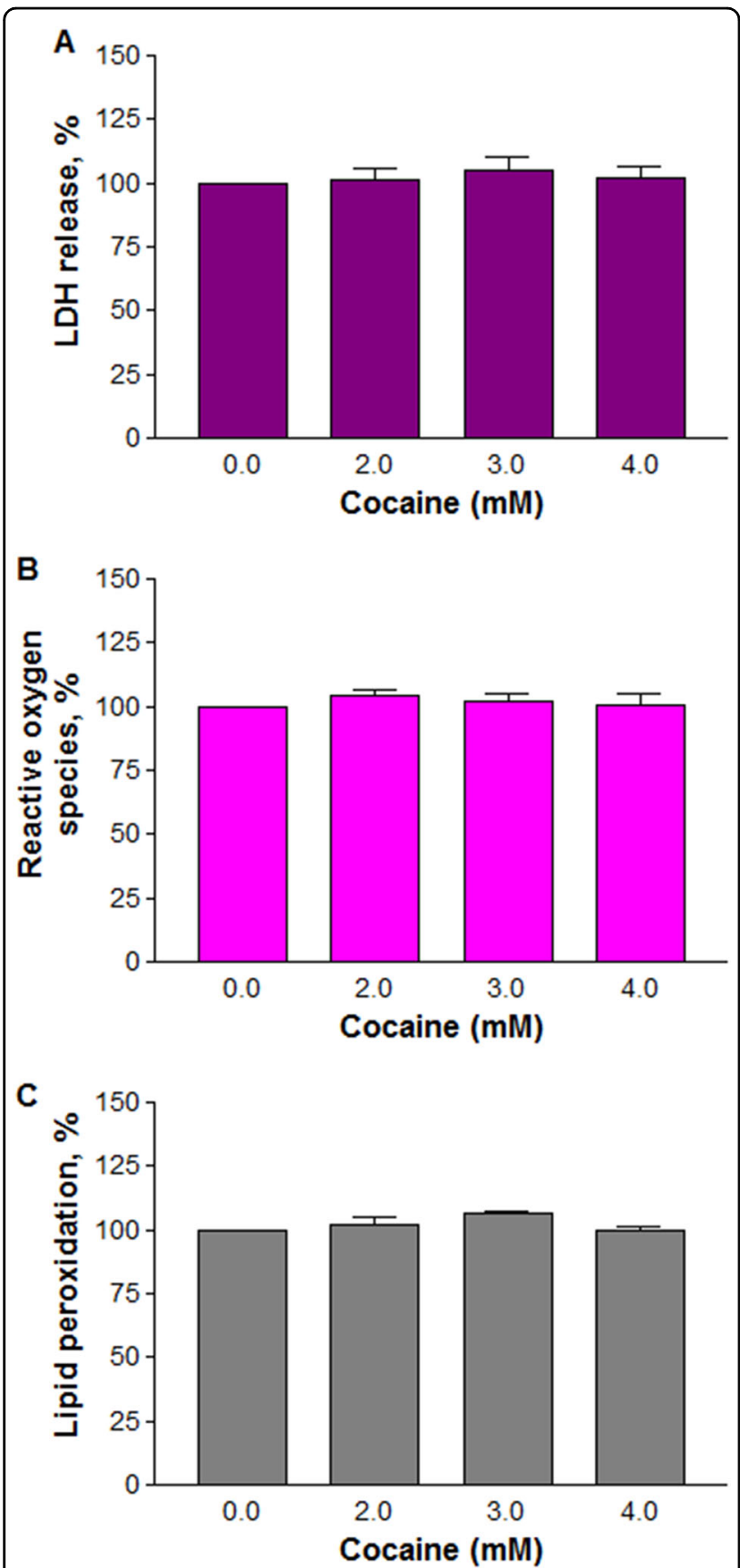

Fig. 4 Effect of cocaine on plasma membrane integrity. The cells were treated with various concentrations of cocaine for $1 \mathrm{~h}$. LDH (a) release $(n=8)$, ROS (b) generation $(n=8)$ or lipid (c) peroxidation $(n=12)$ were measured in a micro plate reader. Data were represented as mean $\pm \mathrm{SEM}, P>0.05$, insignificant compared to control, one-way ANOVA, Dunnett's multiple comparison test

cocaine treated cells compared to the control (Fig. 7c). The increase $( \pm$ SEM) was $108.2 \pm 5.8 \%, 119.9 \pm 3.7 \%$, and 108.7 $\pm 5.2 \%$ compared to the control $(100 \%)$ at 2 , 3 , and $4 \mathrm{mM}$ cocaine, respectively. Hypoxic state did not alter the ATP level $(n=8, P>0.05)$ in cocaine-treated cells (Fig. $7 \mathrm{~d})$.
Cell survival with cocaine treatment was not associated with survivin (Birc5) gene

Because there was no cell death with cocaine treatment at in vitro concentrations, we investigated whether survivin, a member of the anti-apoptotic family of genes ${ }^{21}$, was associated with survival of the cells upon cocaine treatment. Since cell viability was not changed at $4 \mathrm{mM}$ cocaine treatment compared to the control, we measured survivin gene expression only at this dose. There was no significant difference in survivin expression in cocaine treated cells compared to the control (Fig. 8a). To further confirm the result, we pre-treated the cells with $1 \mu \mathrm{M}$ YM155, a survivin inhibitor, for $30 \mathrm{~min}$, followed by cocaine treatment $(2-4 \mathrm{mM})$ for $1 \mathrm{~h}$. There was no change $(n=4, P>0.05)$ in cell survival with cocaine treatment in the presence or absence of YM155 inhibitor (Fig. 8b). Preincubation of cells with $1 \mu \mathrm{M}$ YM155 for $24 \mathrm{~h}$, followed by cocaine (2-4 mM) co-treatment for $1 \mathrm{~h}$ also did not cause cell death (data not shown). These results indicate clearly that the observed neuronal survival with cocaine treatment was not associated with survivin gene.

\section{Cocaine treatment activated Nrf-2 expression and increased antioxidants}

Previous reports showed that $\mathrm{H}_{2} \mathrm{~S}$ release was associated with activation of nuclear factor E2-related factor-2 (Nrf2) as a response to stress ${ }^{22}$. We investigated whether cocaine-induced $\mathrm{H}_{2} \mathrm{~S}$ release (Fig. 7c) could activate $\mathrm{Nrf}-2$ gene expression in N2a neuronal-like cells with cocaine treatment. It was found that there was a significant $\left(n=7-12, F_{(3,47)}=2.5, P<0.05\right)$ upregulation of $\mathrm{Nrf}-2$ gene expression compared to the control (Fig. 8c). The increase was $( \pm$ SEM) $203.8 \pm 50.3$ of the control value (100\%) at $4 \mathrm{mM}$. Since $\mathrm{Nrf}-2$ is known to increase several antioxidant systems ${ }^{23}$, we then measured three antioxidants, namely GSH, catalase, and glutathione peroxidase in cocaine-treated cells. It was found that cocaine treatment caused a significant $\left(n=12, F_{(3,44)}=15.68, P\right.$ $<0.01)$ increase in GSH level compared to the control (Fig. 8d). The GSH levels were $( \pm$ SEM) $114.19 \pm 4.5 \%$, $125.58 \pm 6.0 \%$, and $134.71 \pm 3.4 \%$ of the control value $(100 \%)$ at 2,3 , and $4 \mathrm{mM}$ cocaine, respectively. Similarly, there was a significant increase in catalase $\left[n=3, F_{(3,8)}=\right.$ 7.04, $P<0.05]$ and GPx activities $\left[n=3, F_{(3,8)}=4.35, P\right.$ $<0.05]$ at $4 \mathrm{mM}$ cocaine treatment compared to the corresponding controls (Fig. 8e, f).

\section{Nrf-2 inhibition caused cell death through decreased GSH}

Because cell resistance to high doses of cocaine in our study was due to increased antioxidants through $\mathrm{Nrf}-2$ activation (Fig. 8c-f), we reasoned that inhibition of $N r f-2$ should decrease the level of antioxidants and consequently decrease the cell viability with cocaine treatment. To prove this, we pre-treated the cells with $5 \mu \mathrm{M}$ PIK-75 

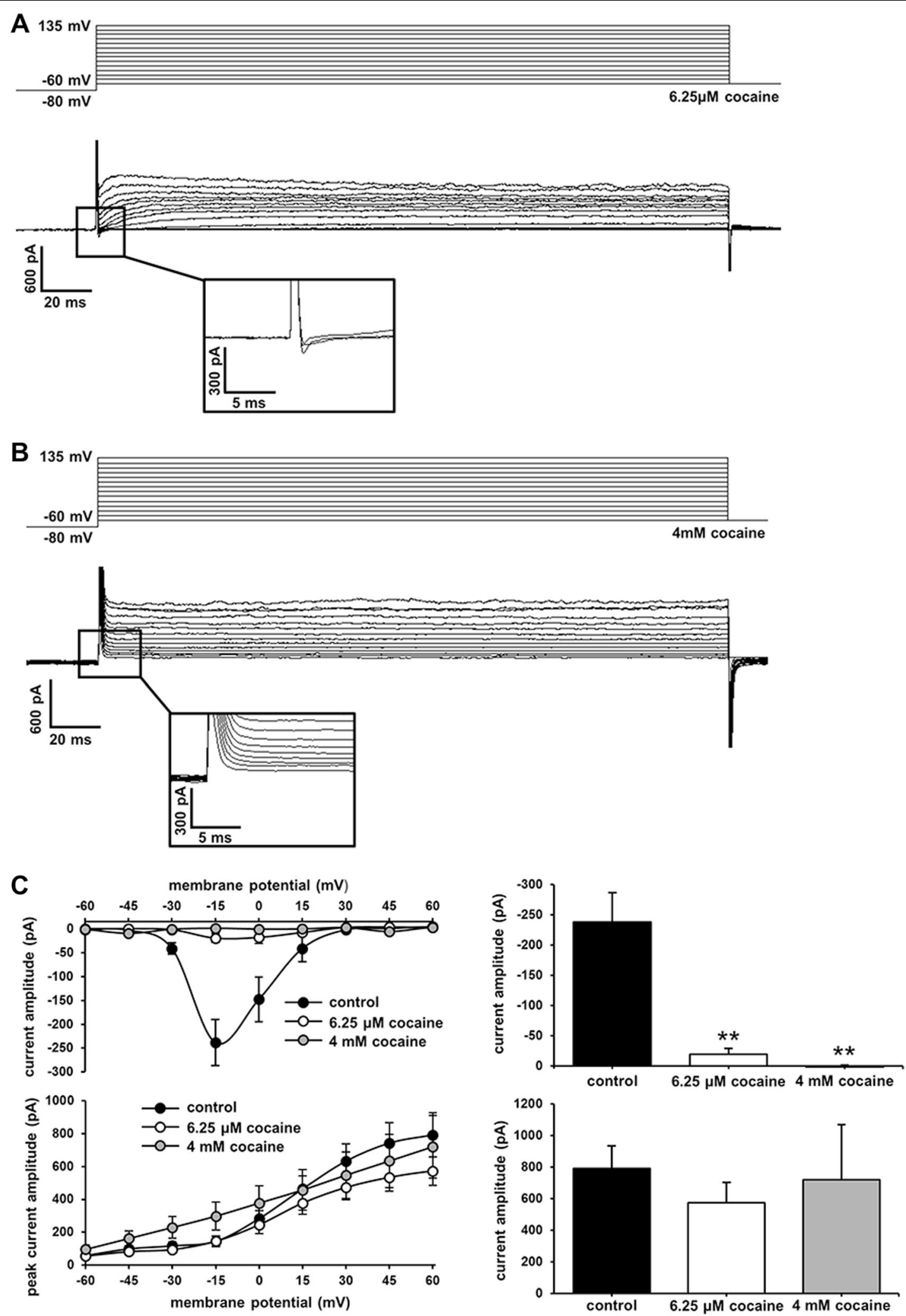

Fig. 5 Cocaine treatment reduces inward current amplitude. Representative voltage clamp trace showing reduced inward currents after a low dose $(6.25 \mu \mathrm{M})$ and $\mathbf{b}$ high dose $(4 \mathrm{mM})$ cocaine treatment. Step size $=15 \mathrm{mV}$. The inset shows a high magnification view of inward currents. $\mathbf{c}$ (Left) Current-voltage relationship of inward currents (top) and outward currents (bottom) measured from untreated, low dose, and high dose cocainetreated N2a cells ( $n=8$ for each group). c (Right) Average peak current amplitude at $-15 \mathrm{mV}$ (top, inward currents) and $+60 \mathrm{mV}$ (bottom, outward currents). ${ }^{* *} P<0.001$, significant in comparison to corresponding controls, one-way ANOVA, Bonferroni's multiple comparison tests 


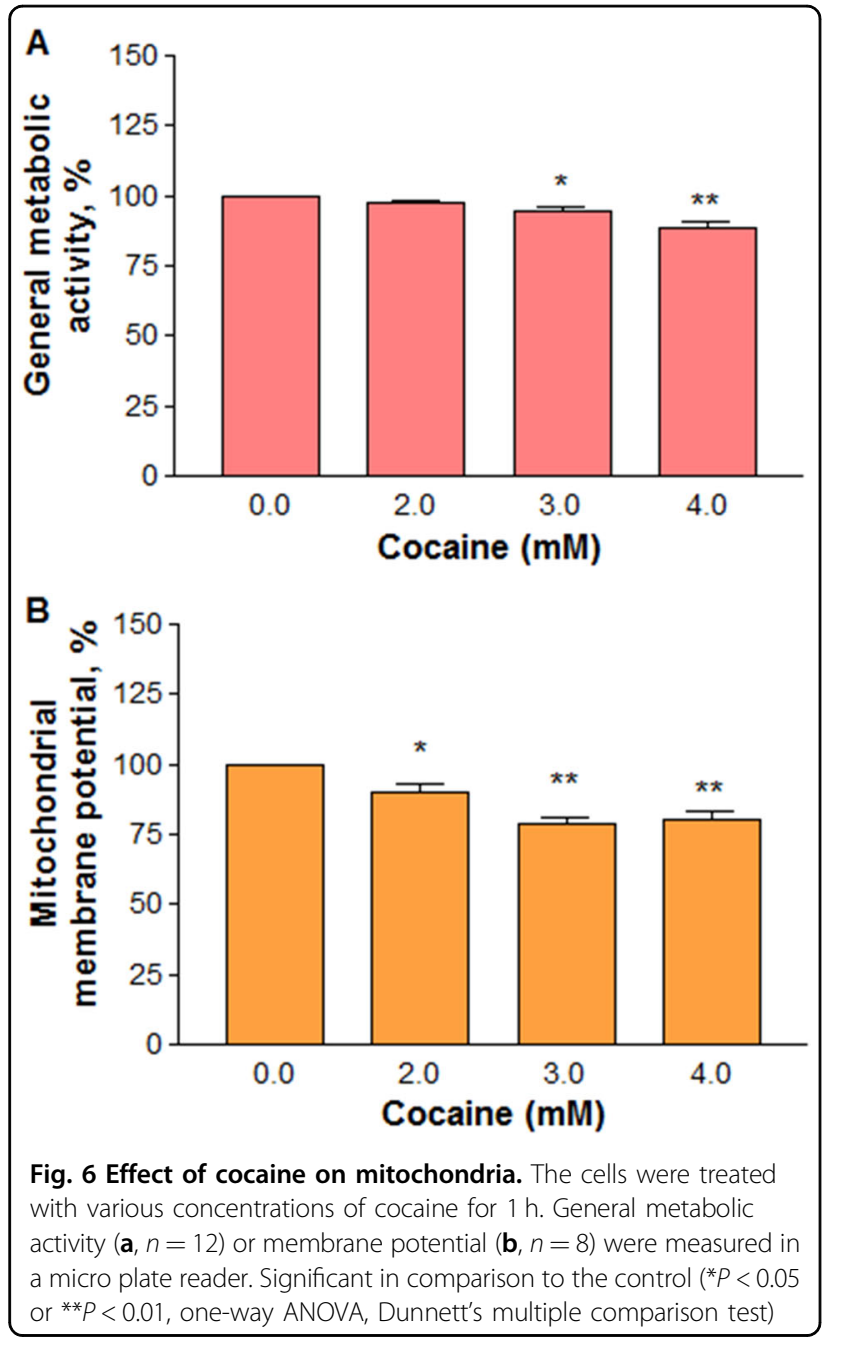

[an inhibitor of $N r f-2]^{24}$ for $30 \mathrm{~min}$, followed by cocaine (2-4 mM) co-treatment for $1 \mathrm{~h}$. PIK-75 alone did not cause cell death $(n=8, P>0.05)$; however, with cocaine co-treatment for $1 \mathrm{~h}$, it caused significant cell death $(n=$ $\left.8, F_{(7,56)}=19.34, P<0.001\right)$. For example, the viability was decreased to $94.8,88.3$ and $71.6 \%$ at 2,3 , and $4 \mathrm{mM}$ cocaine, respectively compared to the control cells (Fig. 8g). Under this condition, we measured the GSH level in the cells. While PIK-75 alone caused significant increase $(119.2 \pm 5.1 \%)$ in GSH level compared to the untreated control $(100 \%, n=8, P<0.05)$, cocaine cotreatment for $1 \mathrm{~h}$ caused significant decrease in the GSH level compared to cocaine-alone-treated group $(n=8$, $\left.F_{(7,56)}=6.352, P<0.001\right)$. For example, the GSH level was decreased to $117.2 \pm 6.0 \%, 96.7 \pm 6.6 \%$, and $87.7 \pm 3.8 \%$ at 2 , 3, and $4 \mathrm{mM}$ cocaine, respectively (Fig. 8h). The decreased GSH level with PIK-75 pre-treatment corresponded with the decreased cell viability. These results prove the involvement of $\mathrm{Nrf}$-2-dependent increase of antioxidants for cell resistance against cocaine.

\section{Discussion}

Besides identifying several early response-changes, the report on the lack of cell death to high cocaine doses in N2a neuronal-like cells was a new observation unknown previously. Assessment of early response-changes under in vivo situation would have been relevant to decipher cocaine action, but direct understanding of those changes is impeded due to body complexity. Cell cultures, on the other hand, offer unique opportunity to explore the mechanism of response under controlled environment, a factor responsible for using in vitro model in this study. Employing primary cultures here is not practical on account of restricted growth potential, finite life span and lack of cell homogeneity. The N2a cells employed in this study have neuronal origin, and upon differentiation functioned as neurons; ${ }^{25,26}$ our results corroborated these reports in terms of morphology (Supplementary Figure S1) and function (Supplementary Figures S2, 4).

The use of higher cocaine doses in our study became imperative owing to lack of effect on morphology (Fig. 1) or viability (Supplementary Figure S3A) at lower concentrations. This necessitated increasing of cocaine concentrations several fold. Under in vitro studies, cocaine concentrations have extended into milli molar range ${ }^{14,15,27,28}$. Thus testing $8.8^{29}, 10^{14,28,30}$, or $13 \mathrm{mM}^{31}$ cocaine at even longer-incubation intervals despite cocaine's relatively short half-life of $\sim 1 \mathrm{~h}^{2-4}$ are not atypical. The highest concentration $(4 \mathrm{mM})$ in our study was 2.2-3.25 times lower compared to $8.8^{29}$ and $13 \mathrm{mM}^{31}$ cocaine, respectively. Therefore, cocaine concentrations tested in our study were in the acceptable range for in vitro research. The use of higher concentrations of cocaine in our study was compared with in vivo administrative and clinical doses, and was explained in detail in the Supplementary results. In spite of high doses, the cells remained viable to acute $(1 \mathrm{~h})$ cocaine treatment (Supplementary Figure S3B). A time-course of study might have revealed loss in the cell viability, as shown in a recent report ${ }^{32}$; however, we did not undertake such a study currently because the intension of acute treatment for $1 \mathrm{~h}$ was to mimic the maximum period of euphoria in cocaine addicts, which usually wears off within $1 \mathrm{~h}$ for typical amounts and routes of intake ${ }^{33}$, and to evaluate various early response-changes within this period because it assists in knowing early sub-cellular targets of cocaine in neurons.

We found that mitochondria were the primary targets of cocaine (Fig. 6a, b). Interestingly, dysfunctional mitochondria (Fig. $6 \mathrm{~b}$ ) did not pose threat to viability of the cells because they survived through anaerobic respiration as evidenced by lactate release (Fig. 7a, b). Since cocaine is cleared off rapidly from the body owing to its short halflife $^{2-4}$, it is possible that one-time cocaine abuse by humans, yielding the pharmacological doses found in the 

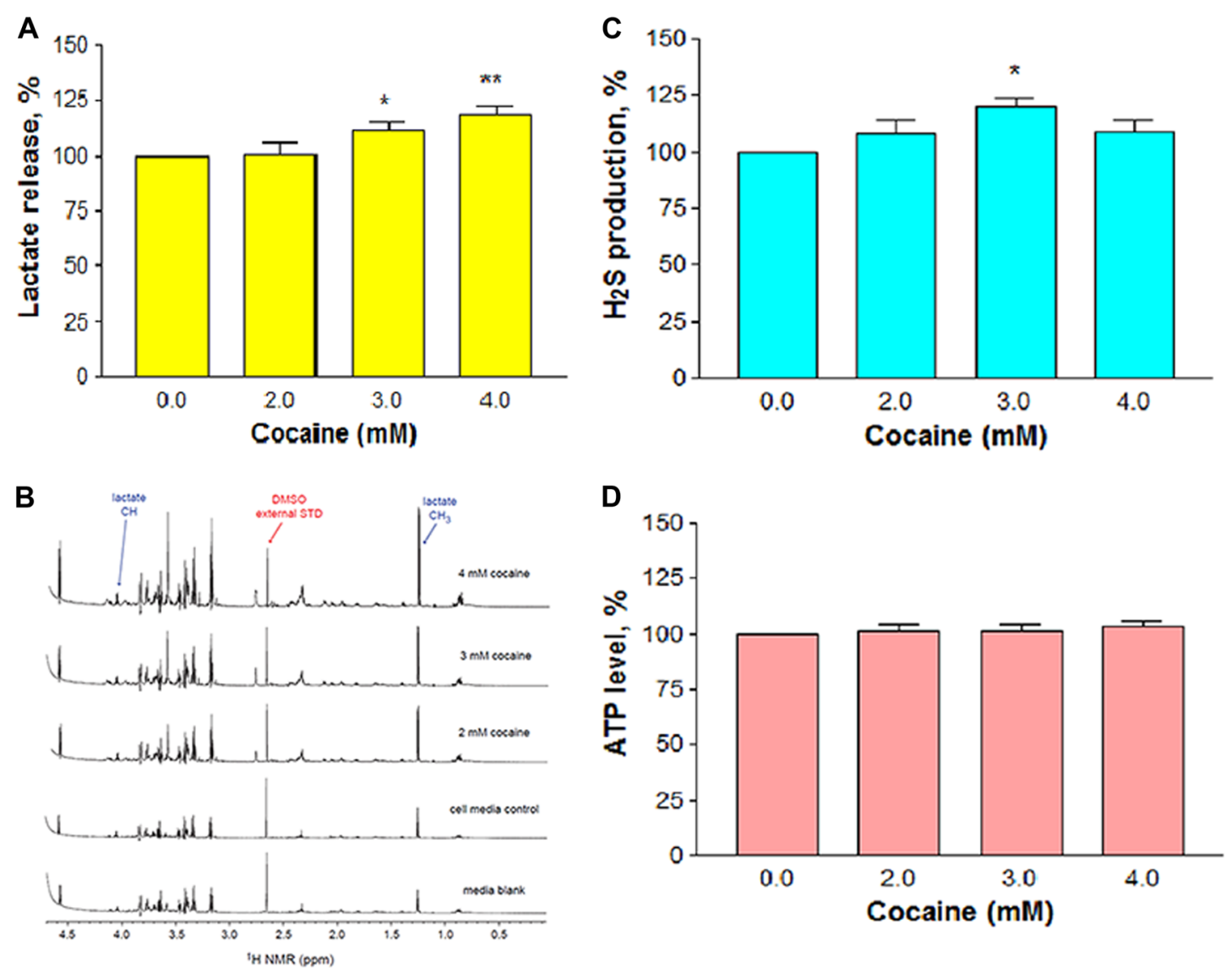

Fig. 7 Cocaine-induced anaerobic characters. The cells were treated with various concentrations of cocaine for 1 h. Lactate was measured by colorimetric (a) method $(n=12)$. Medium from the untreated cells was taken as a control while the medium without cells was used as a blank. Confirmation of lactate release by ${ }^{1} \mathrm{H}^{+} \mathrm{NMR}(\mathbf{b})$ spectroscopy. Lactate peaks are visible in the spectra at $1.25 \mathrm{ppm}$ for the methyl group (doublet) and $4.04 \mathrm{ppm}$ for the methine group (quartet), $\mathbf{c} \mathrm{H}_{2} \mathrm{~S}$ production $(n=16)$, and $\mathbf{d}$ ATP measurement by bioluminescence $(n=8)$. Significant in comparison to the control $\left(* P<0.05\right.$ or ${ }^{* *} P<0.01$, one-way ANOVA, Dunnett's multiple comparison test)

brain $^{13}$, may not affect neurites outgrowth or neuronal viability. Consistence with these observations was the results from animal models with short-term cocaine administration of 50 to $450 \mathrm{mg} / \mathrm{kg} /$ day that neither caused cell death nor induced neurodegenerative changes ${ }^{10,11}$. However, as addicts consume cocaine frequently, it is possible that the cells are affected in the long-run. Echoing these views is the post-mortem examination of several long-term cocaine addicts which showed loss of dopaminergic neurons in striatum and midbrain ${ }^{12}$.

Consistent with earlier reports ${ }^{9,34-37}$, acute cocaine treatment of cells resulted in cytoplasmic vacuolation (Fig. 3; Supplementary Figure S3C). In spite of it, lack of concomitant increase in cocaine toxicity to cells (Supplementary Figure S3B) implies that the formation of vacuoles in these cells was a secondary cause to the toxicity, while in C6 astroglia-like cells, vacuolation appeared as one of the primary events to toxicity ${ }^{6}$. Lack of cell death to acute cocaine treatment in our study is not only in contrast with the general perception of neurons being sensitive to cocaine but also contradicted with previous reports in neuronal cultures ${ }^{14,38-40}$. Variations in culture conditions and incubation periods [e.g., $1 \mathrm{~h}$ acute exposure vs. 2-4 days chronic exposure ${ }^{14,38-40}$ ] are some possible causes of this discrepancy.

Despite hypoxic state (Fig. 7a, b), there was no change in ATP level in cocaine treated cells (Fig.7d). Production of $\mathrm{H}_{2} \mathrm{~S}$ (Fig. 7c) indicated that the unchanged ATP level in treated cells might have resulted through $\mathrm{H}_{2} \mathrm{~S}$ association as shown earlier ${ }^{41}$. Studies also showed that $\mathrm{H}_{2} \mathrm{~S}$ production was involved with the activation of transcription factor $N r f-2$ in response to cellular stress ${ }^{22}$. Coinciding with this report, an up-regulation of $N r f-2$ gene was observed in our study with cocaine treatment (Fig. 8c), suggesting that cocaine exposure triggered the stress signals. In support of $\mathrm{Nrf}-2$ protection through antioxidant system as reported earlier ${ }^{42,43}$, an upregulation of $\mathrm{Nrf}-2$ gene with cocaine treatment was correlated with increased antioxidants (Fig. 8d-f), while their decrease by the treatment of $N r f-2$ inhibitor (PIK-75) decreased the 

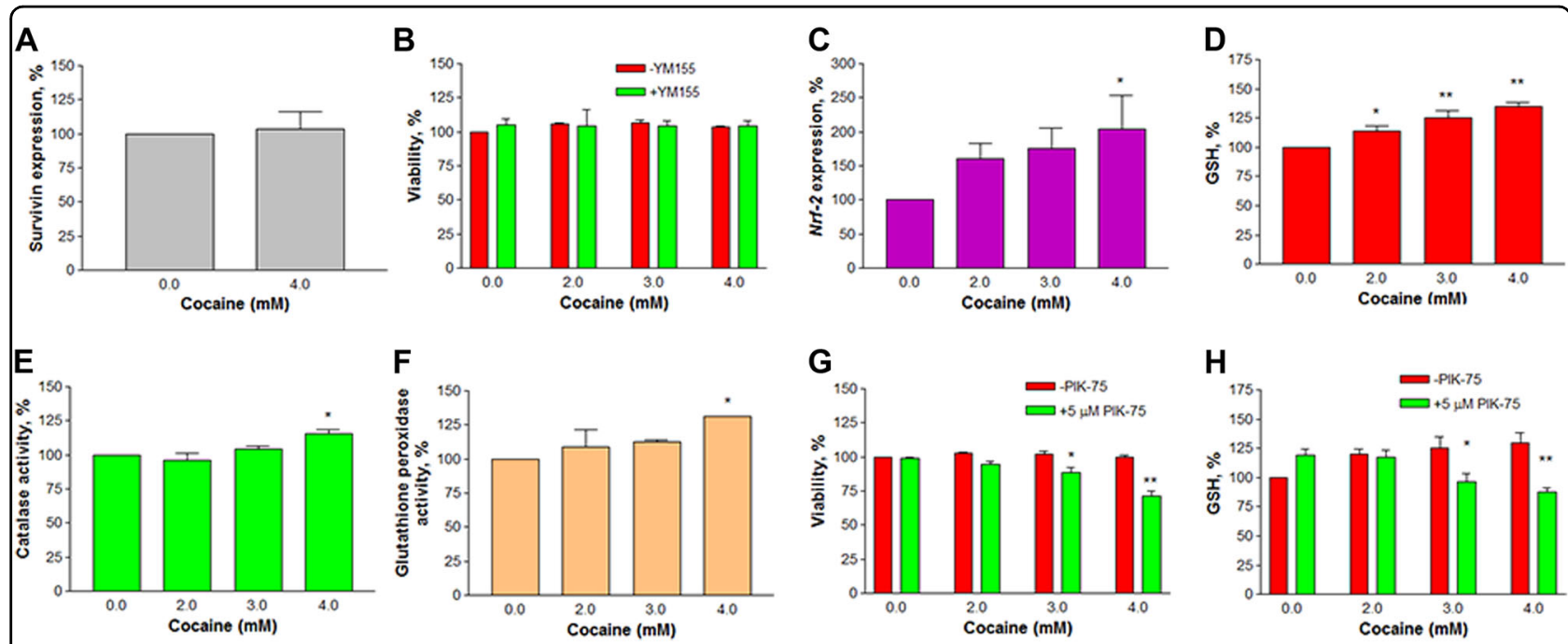

Fig. 8 Effect of cocaine on survivin, Nrf-2, and antioxidants. For survivin gene expression, the mRNA levels in $4 \mathrm{mM}$ cocaine-treated and control cells were quantified $(n=4)$ by real-time PCR using GAPDH as the reference gene $(\mathbf{a})$; in another study, the cells were pretreated with $1 \mu \mathrm{M}$ YM155 (survivin gene inhibitor) for $30 \mathrm{~min}$, followed by cocaine co-treatment for $1 \mathrm{~h}$, and the cell viability was measured ( $n=4$ ) in a micro plate reader (b). For Nrf-2 gene expression, the mRNA level was quantified ( $n=3$ ) by real-time PCR using GAPDH as the reference gene (c). Colorimetric assays were performed for glutathione $(n=9)(\mathbf{d})$ or catalase $(\mathbf{e}, n=3)$ or GPx $(\mathbf{f}, n=3)$ or role of PIK-75 (Nrf-2 inhibitor) on cocaine treated cells for viability $(\mathbf{g}, n=8)$ or glutathione $(\mathbf{h}, n=8)$. Data were represented as mean $\pm \mathrm{SEM}$, significant compared to the control (** $P<0.05$ or ${ }^{* *} P<0.01$, one-way ANOVA, Dunnett's (a, c, d-f) or Bonferroni's (b, $\mathbf{g}, \mathbf{h}$ ) multiple comparison tests)

cell viability with cocaine treatment (Fig. 8g). Because pretreatment of cells with the inhibitor of survivin (YM155) did not cause cell death with cocaine (Fig. 8a, b), it is obvious that the mechanism of cell resistance to cocaine was not of general type; instead, a specific detoxifying strategy through $\mathrm{Nrf}-2$ gene was responsible for cellular resistance against cocaine treatment. Thus, identification of early response-changes with cocaine treatment indeed revealed that the mitochondria were the main sub-cellular targets in the cells, and provided the insights that Nrf-2 gene activation was the underlying mechanism for cellular resistance. This supported our hypothesis.

CNS disorders like Parkinson's disease or Alzheimer disease $^{44}$ or schizophrenia are associated with progressive neuronal loss in the brain. Attempts to cure these diseases were not successful so far. While efforts of curing various CNS diseases are good, their prevention is much better. One of the safest ways to prevent CNS diseases is by achieving neuronal resistance through intracellular regulation. Even though there was no direct relevance of our study to neurodegenerative disorders, we attempted to extrapolate the concept of neuronal "resistance" (lack of cell death) observed in our study to CNS disorders.

For instance, the knowledge on factors responsible for resisting neuronal cell death may be exploited in delaying the onset or progression of neurodegenerative disorders through intracellular regulation. Such feasibility was demonstrated both in vivo and in vitro situations. Studies showed that up-regulation of DJ-1 gene prevented the progression of Parkinson's disease in animal models ${ }^{45}$. In a similar approach under in vitro condition, we showed the resistance of cells to toxins $\left(\mathrm{MPP}^{+}\right.$and cocaine) through intracellular regulation ${ }^{6,46}$. These studies clearly demonstrated the practical side of achieving cell resistance to toxins MPP $^{+6}$ and cocaine ${ }^{46}$ ] or [Parkinson's ${ }^{45}$ or Alzheimer's ${ }^{47}$ ] diseases through intracellular regulation. Thus, achieving neuronal resistance through intracellular (up/down) regulation of some gene/s (e.g., Nrf-2) by pharmacological boosting could protect and delay the onset or progression of neurodegenerative disorders. We guesstimate that this approach may facilitate a novel therapeutic strategy for CNS diseases in future.

\section{Materials and methods \\ Materials}

RPMI 1640, FBS, penicillin/streptomycin sulfate, amphotericin B, PBS, and L-glutamine, were purchased from Media Tech (Herndon, VA). Crystal violet, rhodamine 123 (Rh 123), L glutaraldehyde, trypan blue, cocaine- $\mathrm{HCl}$ (Ecgonine methyl ester benzoate, MW: 339.8), $2^{\prime}, 7^{\prime}$-dichlorofluorescin diacetate $\left(\mathrm{H}_{2} \mathrm{DCFDA}\right), 5,5$-dithiobis-2-nitrobenzoic acid (DTNB), nicotinamide adenosine dinucleotide phosphate (NADPH) and ethylene diamine tetraacetic acid (EDTA) were supplied by Sigma Chemical Company (St. Louis, MO). The Nrf-2, survivin (Birc5), and GAPDH oligonucleotide primers were obtained from Eurofins Genomics (Louisville, KY). PIK-75 hydrochloride (inhibitor of $N r f-2$ ) was purchased from Santa Cruz 
Biotechnology, Inc. (Dallas, TX). Survivin inhibitor YM 155 was obtained from Calbiochem (San Diego, CA). All other routine chemicals were of analytical grade.

\section{Cell culture}

The N2a cells (CCL-131, ATCC) were maintained as a monolayer culture ${ }^{48}$, and has been widely employed for studies on substances of abuse $\mathrm{e}^{14,49,50}$ or CNS disorders like Parkinson's ${ }^{51}$ or Alzheimer's diseases ${ }^{47,52,53}$. One advantage of this cell line is that the fine morphological changes due to any chemical exposure can easily be detected on account of their larger cell size. Unless otherwise specified, all experiments in our study were carried out in phenol red free RPMI-1640 medium containing 10\% FBS. Post-seeded cells in culture plates or dishes were allowed to grow 4-5 days in the incubator for spontaneous differentiation of neurite outgrowths. All studies were repeated at least twice.

\section{Morphology}

For gross cell morphological evaluations, crystal violet stained cells ${ }^{37}$ were photomicrographed using EVOS Cell Imaging Systems with $\times 40$ objective. In some studies, morphology or vacuoles of crystal violet-stained cells were taken using an inverted phase contrast IX-70 Olympus microscope. Neurite outgrowths were quantified using image J software (National Institutes of Health).

\section{Electrophysiology}

Whole-cell patch clamp was used to record from N2a cells cultured on plastic cover slips. Cover slips were washed three times with extracellular recording solution containing (in $\mathrm{mM}$ ) $145 \mathrm{NaCl}, 2 \mathrm{KCl}, 2 \mathrm{CaCl}_{2}, 2 \mathrm{MgCl}_{2}$, 10 glucose, and 10 HEPES ( $312 \mathrm{mOsm}, \mathrm{pH} 7.4$ ) and were incubated in this solution at room temperature. Cover slips were either left untreated or treated with $6.25 \mu \mathrm{M}$ or $4 \mathrm{mM}$ cocaine directly in the extracellular solution during recording. Glass electrodes (resistance 1-5 M $\Omega$ ) were filled with intracellular solution containing (in $\mathrm{mM}$ ) 130 $\mathrm{KCl}, 2 \mathrm{NaCl}, 10 \mathrm{HEPES}$, and 5 EGTA $(292 \mathrm{mOsm}, \mathrm{pH}$ 7.4). Cells were visualized under phase contrast with a Nikon Eclipse Ti-U inverted microscope and attached DSQi1 monochrome digital camera.

Recordings were made with an Axopatch 200B amplifier (Molecular Devices, CA) and digitized with a Digidata 1440A system (Molecular Devices, CA). Ionic currents were recorded under a voltage clamp protocol $(-60$ to $135 \mathrm{mV}$ in $15 \mathrm{mV}$ steps, $250 \mathrm{~ms}$ in duration). Spontaneous postsynaptic currents were recorded under continuous voltage clamp at $-80 \mathrm{mV}$ for $2 \mathrm{~min}$. A current clamp protocol $(-100$ to $200 \mathrm{pA}$ in $20 \mathrm{pA}$ steps, $800 \mathrm{~ms}$ in duration) was used to assess the ability of N2a cells to fire action potentials in response to current injection. Signals were filtered at $1 \mathrm{kHz}$ and sampled at $10 \mathrm{kHz}$. Data were collected and analyzed using pCLAMP 10 software (Molecular Devices, CA).

\section{Treatments}

A known amount of cocaine hydrochloride was dissolved in phosphate-buffered saline (PBS) as $1 \mathrm{M}$ stock just prior to the assays. In order to simulate in vivo pharmacological concentrations of cocaine, ranging from $1 \mathrm{nM}$ to $6.25 \mu \mathrm{M}$, several working stocks $(0.04,0.2,0.4,1$, $2,4,8,20,40,200$, and $400 \mu \mathrm{M})$ were prepared in PBS; similarly, for higher cocaine concentrations $(2,3$, and $4 \mathrm{mM}$ final), working stocks of 80,120 , and $160 \mathrm{mM}$ were prepared in PBS. From each working stock, $5 \mu$ l cocaine was added per well to achieve desired concentrations as well as to prevent $\mathrm{pH}$ alterations in culture medium ${ }^{37}$. Final volume in each well was $200 \mu \mathrm{l}$. While the selection of lower concentrations was based on the reports of nano to lower micro molar cocaine in CNS cells of addicts ${ }^{13}$, the higher concentrations were based on several in vitro studies $^{14-16}$. Cells with medium alone or equal volume of vehicle (PBS) in medium served as controls, while medium devoid of cells was taken as a blank. Based on our previous studies in C6 astroglia-like cells ${ }^{6}$, cocaine treatments in the present study were also carried out for $1 \mathrm{~h}$ for comparison purposes. Incidentally, cocaine effect in addicts wears off within this period for typical amounts and routes of intake ${ }^{33}$. In a subset of experiments, the cells in 96-well plates were pre-treated with $1 \mu \mathrm{M}$ YM155, an inhibitor of survivin gene, for $30 \mathrm{~min}$, followed by cocaine (2-4 mM) co-treatment for $1 \mathrm{~h}$ and evaluated for cell viability, while in other studies, the cells were pretreated with $5 \mu \mathrm{M}$ PIK-75, an inhibitor of $\mathrm{Nrf}-2^{24}$, for $30 \mathrm{~min}$ prior to cocaine co-treatment $(2-4 \mathrm{mM})$ for $1 \mathrm{~h}$ and evaluated for cell viability and GSH levels.

\section{Viability and vacuolation}

Cell viability was assessed by crystal violet dye-uptake as described previously ${ }^{54,55}$. The extent of vacuolation in cells was quantified in glutaraldehyde fixed cells by neutral red dye uptake as described earlier ${ }^{56}$. The dye was extracted with $70 \%$ ethanol and $0.37 \%$ hydrochloric acid, and the absorbance at $540 \mathrm{~nm}$ was taken in a plate reader. Crystal violet stained cells were used for photomicrograph of vacuoles using an inverted phase contrast IX-70 Olympus microscope with a $\times 40$ objective.

\section{Video microscopy}

For live videography, one of the ocular lenses of the inverted phase contrast IX-70 Olympus microscope was replaced with a standard ocular video-camera system. The outlet of the video connector was attached to a computer for image visualization on the monitor using the Electronic Ocular -R-AMCap software program, supplied by Zhejiang JinCheng Scientific \& Technology Co., Ltd, 
(HangZhou, China). Video documentation was taken at a speed 14 frames per second.

\section{Cell membrane integrity assay}

Cell membrane integrity was determined by measuring the release of cytoplasmic LDH with CytoTox 96 nonradioactive assay kit (Promega, Madison, WI) as per the instructions provided by the manufacturer. In brief, the cells in 96-well microtiter plates were treated with various concentrations of cocaine $(2,3$, and $4 \mathrm{mM})$ for $1 \mathrm{~h}$. Then $50 \mu \mathrm{l}$ of test medium was transferred into a new 96-well plate, mixed with equal volume of substrate mix from the kit, and incubated for $30 \mathrm{~min}$ at $37^{\circ} \mathrm{C}$. Absorbance was taken in a plate reader at $490 \mathrm{~nm}$.

\section{Measurement of intracellular ROS}

Cells in 96-well plates were treated with cocaine at 2, 3, and $4 \mathrm{mM}$ for $1 \mathrm{~h}$, followed by staining with a cell permeable dye $\mathrm{H}_{2}$ DCFDA ( $10 \mu \mathrm{M}$ final) for $30 \mathrm{~min}^{6}$. After gentle washing and air drying of the cells, PBS $(100 \mu \mathrm{l} /$ well) was added. The plates were read with the excitation filter set at $485 \mathrm{~nm}$ and the emission filter at $530 \mathrm{~nm}$ in an automatic reader BioTek $^{\mathrm{m}}$ Synergy HTX multimode micro plate reader, BioTek Instruments, Winooski, VT).

\section{Lipid peroxidation assay}

Cells were seeded at a starting density of $0.3 \times 10^{6}$ cells per well in six-well plates. Lipid peroxidation was measured as described earlier ${ }^{57}$. In brief, after cocaine treatment at 2, 3, and $4 \mathrm{mM}$ for $1 \mathrm{~h}$, the cells were harvested and centrifuged at $13,000 \mathrm{rpm}$ on a table top micro centrifuge for $6 \mathrm{~min}$. All cell pellets were sonicated in PBS on ice for $3 \mathrm{~s}$ and transferred into glass tubes. Then the lysates were mixed with $30 \%$ trichloroacetic acid, $0.37 \%$ thiobarbituric acid (TBA). The mixture was boiled for $10 \mathrm{~min}$, cooled to room temperature (RT), transferred into new falcon tubes and centrifuged at $3038 \times g$ for $10 \mathrm{~min}$. The clear supernatant was transferred into 96-well plate and absorbance at $535 \mathrm{~nm}$ was measured in a micro plate reader. Clear medium without cells was used as a blank.

\section{General mitochondrial metabolic activity and membrane potential}

Cells $\left(2 \times 10^{4}\right)$ were treated with various concentrations of cocaine $(2,3$, and $4 \mathrm{mM})$ for $1 \mathrm{~h}$ in 96 -well microtiter plates. Then the plates were centrifuged at $304 \times g$ for $4 \mathrm{~min}$, and the cocaine containing medium was discarded carefully. After adding fresh medium to cells $(200 \mu \mathrm{l})$ immediately, $10 \mu \mathrm{l}$ of MTS (3-(4,5-dimethylthiazol-2-yl)-5 (3-carboxymethonyphenol)-2-(4-sulfophenyl)-2H-tetrazolium, Promega) was added per well as reported earlier ${ }^{58}$ and incubated for $30 \mathrm{~min}$ at $37^{\circ} \mathrm{C}$. Absorbance was taken in a micro plate reader at $490 \mathrm{~nm}$. Membrane potential was assayed as per the earlier procedure ${ }^{46}$. At the end of $1 \mathrm{~h}$ treatment with cocaine, the monolayer cells were overlaid with $100 \mu \mathrm{l}$ of $0.25 \%$ aqueous glutaraldehyde for fixation, containing $R \mathrm{Rh} 123$ to yield a final concentration of $2.6 \mu \mathrm{M}$ for $30 \mathrm{~min}$ at RT. The supernatant was discarded, and the plates were washed with water and air dried in the hood. Finally, $100 \mu \mathrm{l}$ of $0.1 \%$ Triton $\times 100$ in PBS was added per well and incubated at $37^{\circ} \mathrm{C}$ for $1 \mathrm{~h}$. The plates were read with the excitation filter set at 485 $\mathrm{nm}$ and the emission filter at $538 \mathrm{~nm}$ on a BioTek ${ }^{\mathrm{Tm}}$ Synergy $^{\text {rm }}$ HTX multi-mode micro plate reader.

\section{Lactate detection}

Studies conducted on cells grown in medium containing $10 \%$ FBS gave high background values due to serum interaction with some of the kit components (Trinity Biotech, Jamestown, NY). So, in our subsequent studies, prior to the treatments, $10 \%$ FBS containing medium was replaced with reduced serum (0.1\% FBS) in 96-well microtiter plates $\left(2 \times 10^{4}\right.$ cells per well). The kit reagent was dissolved in chromogenic solution that consisted of $5.3 \mathrm{mM}$ vanillic acid, $2.9 \mathrm{mM}$ 4-amino antipyrine, and about 4 units of horseradish peroxidase. At the end of $1 \mathrm{~h}$ cocaine treatment, the kit reagent was added directly to the wells $(20 \mu \mathrm{l}$ per $200 \mu \mathrm{l})$ and the plates were kept in the incubator at $37^{\circ} \mathrm{C}$ for color development $(5-10 \mathrm{~min})$. Absorbance from the untreated cells was taken as a control, while the medium devoid of cells was taken as a blank. Absorbance was measured at $490 \mathrm{~nm}$ in a micro plate reader.

\section{NMR spectroscopy}

Lactate release from the cells was detected by proton $\left({ }^{1} \mathrm{H}^{+}\right)$NMR spectroscopy. Since the amount of serum does not interfere in this method, we used $10 \%$ FBS in medium in 96-well microtiter plates $\left(2 \times 10^{4}\right.$ cells $/ 200 \mu \mathrm{l}$ per well). At the end of $1 \mathrm{~h}$ cocaine treatment, medium $(0.15 \mathrm{ml}$ per well) from all replicates $(n=12)$ of each treatment was pooled $(1.8 \mathrm{ml})$ in the labeled tubes. Medium from the untreated cells was used as a control. Because the treated samples contained $2-4 \mathrm{mM}$ cocaine, we added cocaine ( $4 \mathrm{mM}$ final) to the media blank. NMR analyses were carried out on Bruker Avance 800 ( $\nu_{0}[1 \mathrm{H}]=800.23 \mathrm{MHz}$ ) that is equipped with a TCI $800 \mathrm{S6}$ H-C/N-D-05 Z cryoprobe (the maximum $z$-field gradient strength is $48 \mathrm{G} / \mathrm{cm}$ ). For obtaining one-dimensional (1D) NMR spectrum, 16 transients were acquired and coadded with $3 \mathrm{~s}$ of acquisition delay. Data points $(32,000)$ were employed for obtaining a spectral width of $7500 \mathrm{~Hz}$. The dominant water peak positioned at $4.75 \mathrm{ppm}$ in the spectrum was eliminated by using the WATERGATE W5 pulse sequence ${ }^{20}$. A bandwidth of $3000 \mathrm{~Hz}$ along each side of the water peak was given as a spectral window for observing solute peaks by employing a delay time 
of $333.3 \mu \mathrm{s}$ for the WATERGATE pulse trains. An external standard, $3.3 \mathrm{mM}$ aqueous DMSO solution, was prepared for the quantification of the lactate in the sample solution.

\section{Measurement of $\mathrm{H}_{2} \mathrm{~S}$ in cell culture medium}

Cells were seeded at a starting density of $2 \times 10^{4}$ per well in 96-well plates. Prior to cocaine treatment, $1.64 \%$ aqueous zinc acetate ${ }^{59,60}$ (final: $0.041 \%$ ) was added to cells to convert volatile $\mathrm{H}_{2} \mathrm{~S}$ gas into zinc sulfide during cocaine treatment. After $1 \mathrm{~h}$ of treatment with 2,3 , and $4 \mathrm{mM}$ cocaine, $\quad 17.453 \mathrm{mM} \mathrm{N}, \mathrm{N}$-dimethyl-p-phenylenediamine sulfate in $7.2 \mathrm{M} \mathrm{HCl}$ (final: $2.55 \mathrm{mM}$ ) and $26.18 \mathrm{mM} \mathrm{FeCl}_{3}$ in $1.2 \mathrm{M} \mathrm{HCl}$ (final: $3.83 \mathrm{mM}$ ) were added to the wells and vortexed gently. Bubbles in medium were removed by adding $5 \mu \mathrm{l}$ of cold ethanol to all wells just before reading the plates at $670 \mathrm{~nm}$ in a micro plate reader.

\section{ATP bioluminescence assay}

Cells in 96-well microtiter plates were treated with various concentrations of cocaine $(2,3$ and $4 \mathrm{mM})$ for $1 \mathrm{~h}$. Total ATP was measured using Bioluminescent ATP Somatic cell assay kit (FLASC, Sigma-Aldrich) as per the kit instructions supplied by the manufacturer. In brief, at the end of treatment, $75 \mu \mathrm{l}$ of Somatic Cell ATP releasing solution was added per well to lyse the cells. Then $50 \mu \mathrm{l}$ lysate was transferred into new white, clear bottom 96well plates, which already contained $50 \mu \mathrm{l}$ of ATP assay mix enzyme under reduced light. Luminescence was measured immediately on a BioTek ${ }^{\mathrm{mm}}$ Synergy $^{\mathrm{mm}}$ HTX multi-mode micro plate reader.

\section{Isolation of RNA and CDNA synthesis}

The cells were seeded at a density of $2 \times 10^{6}$ in $100 \mathrm{~mm}$ diameter culture dishes. At the time of treatment, the cells reached around $65-70 \%$ confluence. After $1 \mathrm{~h}$ treatment with $2-4 \mathrm{mM}$ cocaine, the cells were harvested by scrapping and centrifuged at $1125 \times g$ for $5 \mathrm{~min}$. Total RNA was isolated as per the protocol supplied by the manufacturer (Qiagen Sciences, German town, MD) using RNeasy mini spin columns. DNase I (Qiagen Sciences) treatment was performed on the column. Total RNA from the column was eluted with $20 \mu \mathrm{l}$ of RNase free water. For the sake of quantification, the RNA on ice was diluted in RNase free water at 1:10 ratio. The quantity of total RNA was measured by the Nanodrop ND-1000 spectrophotometer (NanoDrop Technologies, Wilmington, DE). The RNA showed a ratio of $>1.95$ at $260 / 280 \mathrm{~nm}$, and was subsequently used for cDNA synthesis. One microgram of total RNA was used to produce cDNA using an iScript cDNA synthesis Kit (Bio-Rad, Hercules, CA) according to the manufacturer's instructions.

\section{Relative expression by quantitative RT-PCR}

Gene expression analysis of Nrf-2, survivin (Birc5), and GAPDH by qPCR was performed in an iCycler thermal cycler with MyiQ detection system (Bio-Rad) using iQ SYBR Green supermix. Nrf-2, survivin, and GAPDH products were synthesized by separate PCR reactions, carried out in $20 \mu \mathrm{l}$ final volume with $2 \mu \mathrm{l}$ of cDNA sample and $500 \mathrm{nM}$ of specific primers. Cycling conditions were as follows: $95^{\circ} \mathrm{C}$ for $10 \mathrm{~min}$, followed by 40 cycles of $95^{\circ} \mathrm{C}$ for $15 \mathrm{~s}, 55^{\circ} \mathrm{C}$ for $30 \mathrm{~s}$ and $72^{\circ} \mathrm{C}$ for $30 \mathrm{~s}$, while melt curve analysis following PCR was performed at $55-95^{\circ} \mathrm{C}$. The relative quantification of gene expressions was performed according to $2^{-\triangle \triangle \mathrm{CT}}$ method $^{61}$ with GAPDH as the endogenous control. The primer sequences used for analyses are shown in Table 1.

\section{Total GSH assay}

After treating with different concentrations of cocaine (2-4 mM) in complete medium for $1 \mathrm{~h}$ in 96-well microtiter plates, the cells were fixed with $0.25 \%$ glutaraldehyde for $30 \mathrm{~min}$, followed by gentle washing three times, and air dried. Total cellular GSH was assayed as described earlier ${ }^{62}$. The absorbance was measured at $412 \mathrm{~nm}$ in a micro plate reader.

\section{Preparation of whole-cell lysates}

For enzyme assays, cells were seeded at a density of $2 \times 10^{6}$ in $100 \mathrm{~mm}$ diameter culture dishes. After $1 \mathrm{~h}$ treatment with $2-4 \mathrm{mM}$ cocaine, the cells were harvested

Table 1 Primer sequences

\begin{tabular}{|c|c|c|c|}
\hline Gene name & Accession/nucleotide position & Primers & Fragment length \\
\hline Nrf-2 & $\begin{array}{l}\text { NCBI:NM } 010902.4 \text { (Nucleotides: } \\
\text { 1468-1488) }\end{array}$ & 5'-CACAGTGCTCCTATGCGTGAA-3' 5'-TTTGTGAATGGGGCTTाTTGA-3' & $92 \mathrm{bp}$ \\
\hline $\begin{array}{l}\text { Survivin } \\
\text { (Birc5) }\end{array}$ & NCBI:NM 009689.2 (Nucleotides: 492-512) & 5'-GACTGCAAAGACTACCCGTCA-3' 5'-GATGTGGCATGTCACTCAGG-3' & $94 \mathrm{bp}$ \\
\hline GAPDH & $\begin{array}{l}\text { NCBI:NM } 001289726.1 \text { (Nucleotides: } \\
\text { 832-853) }\end{array}$ & 5'-TGGAGAAACCTGCCAAGTATGA-3' 5'-TGGTCCTCAGTGTAGCCCAAG-3' & $94 \mathrm{bp}$ \\
\hline
\end{tabular}


using cell scrappers. After centrifugation at $1620 \times g$ for $5 \mathrm{~min}$, the cell pellets were stored at $-70^{\circ} \mathrm{C}$ until further use. On the day of assays, the pellets were re-suspended in $0.5 \mathrm{ml} \mathrm{PBS}$ and sonicated twice on ice for $15 \mathrm{~s}$. The contents were transferred to eppendorf tubes and microcentrifuged at $5000 \mathrm{rpm}$ for $5 \mathrm{~min}$. The supernatants were transferred to new tubes and used for enzyme assays. Protein concentration in each lysate was determined using BCA protein assay kit (Pierce, Rockford, IL) as per manufacturer's instructions taking bovine serum albumin as a standard reference.

\section{Catalase assay}

It was assayed as per the earlier method ${ }^{63}$. The reaction mixture $(450 \mu \mathrm{l})$ in a quartz cuvette contained $50 \mu \mathrm{l}$ of cell lysate $(60 \mu \mathrm{g}), 250 \mu \mathrm{l}$ of $50 \mathrm{mM}$ phosphate buffer ( $\mathrm{pH} 7.0)$. The reaction was started by the addition of $150 \mu \mathrm{l}$ of 30 $\mathrm{mM} \mathrm{H}_{2} \mathrm{O}_{2}$ (10 $\mathrm{mM}$ final). The decrease in absorbance at $240 \mathrm{~nm}$ was monitored for $2 \mathrm{~min}$ in a Genesys $10 \mathrm{~S} \mathrm{UV}$ Vis spectrophotometer (Thermo Scientific, Vernon Hills, IL). The enzyme activity was calculated using the extinction coefficient of 0.00706 per $\mathrm{mmol}$ per $\mathrm{mm}$ and the unit of enzyme activity was expressed as $m m o l ~ \mathrm{H}_{2} \mathrm{O}_{2}$ decomposed per minute per mg protein. Then the enzyme activity of treated samples was compared with the control (100\%).

\section{GPx assay}

It was assayed as per the published procedure ${ }^{64}$. The reaction mixture $(500 \mu \mathrm{l})$ contained $1 \mathrm{mM} \mathrm{GSH}, 0.15 \mathrm{mM}$ $\mathrm{NADPH}, 0.12$ unit glutathione reductase (GR), $0.1 \mathrm{mM}$ sodium azide in $0.1 \mathrm{M}$ potassium phosphate $(\mathrm{pH} 7.0$ with $1 \mathrm{mM}$ EDTA. Sodium azide was added to the reaction mixture to inhibit endogenous catalase activity. The reaction mixture was incubated with $60 \mu \mathrm{g}$ of sample for 10 min without NADPH, and the reaction was started by the addition of NADPH and $\mathrm{H}_{2} \mathrm{O}_{2}$ at a final concentration of $150 \mu \mathrm{M}$. The rate of NADPH consumption was monitored at $340 \mathrm{~nm}$ for $3 \mathrm{~min}$. One unit of GPx activity was defined as the amount of enzyme required to consume $1 \mu \mathrm{mol}$ of $\mathrm{NADPH} / \mathrm{min}$ in the coupled assay and activity was expressed per $\mathrm{mg}$ of protein. Then the enzyme activity of treated samples was compared with the control (100\%).

\section{Statistical analysis}

The experimental results ( $n=$ number of wells pooled from at least two different experiments) were presented as the mean \pm SEM. All bar graphs were plotted using a GraphPad Prism Software, version 3.00 (San Diego, CA). The data were analyzed for significance by one-way ANOVA and then compared using Dunnett's or Bonferroni's multiple comparison tests. The test values of $P<0.05$ and $P<0.01$ were considered significant and highly significant, respectively.

\section{Acknowledgements}

This work was supported by the National Institute on Minority Health and Health Disparities of the National Institutes of Health under award number G12MD007582, P20 MD006738 and the National Institute of General Medical Sciences of the National Institutes of Health under Award Number R25GM107777. Parts of this work were performed at the National High Magnetic Field Laboratory (NHMFL), which is supported by NSF DMR-1157490, DMR-1644779 to S.W., J.T.R. and S.C.G. and the State of Florida, National Institutes of Health grant MH115188 to Y.Z. and National Science Foundation Grant GRFP 1449440 to Z.J. The content is solely the responsibility of the authors and does not necessarily represent the official views of the National Institute of Health. We thank Dr. Emily C. Bruggeman for reading the manuscript and for suggestions.

\section{Authors' contributions}

R.B.B., C.B.G., S.C.G. and L.M.L. conceived and designed the research. R.B.B., S.W. Z.J., E.M. and J.T.R. performed the research. R.B.B., S.W., Z.J. and E.M. analyzed the data. R.B.B., S.W., Z.J., Y.Z. and E.M. wrote the paper.

\section{Author details}

${ }^{1}$ College of Pharmacy and Pharmaceutical Sciences, Florida A\&M University, Tallahassee, FL 32307, USA. ${ }^{2}$ The National High Magnetic Field Laboratory, Florida State University, Tallahassee, FL 32310, USA. ${ }^{3}$ Department of Biomedical Sciences, Florida State University College of Medicine, Tallahassee, FL 32306, USA. ${ }^{4}$ Department of Biological Science, Florida A\&M University, Tallahassee, FL 32307, USA

\section{Conflict of interest}

The authors declare that they have no conflict of interest.

\section{Publisher's note}

Springer Nature remains neutral with regard to jurisdictional claims in published maps and institutional affiliations.

The online version of this article (https://doi.org/10.1038/s41420-018-0078-x) contains supplementary material, which is available to authorized users.

Received: 17 May 2018 Revised: 11 June 2018 Accepted: 22 June 2018 Published online: 17 July 2018

\section{References}

1. Haas, C., Karila, L. \& Lowenstein, W. Cocaine and crack addiction: a growing public health problem. Bull. Acad. Natl. Med. 193, 947-962 (2009).

2. Wilkinson, P., Van Dyke, C., Jatlow, P., Barash, P. \& Byck, R. Intranasal and oral cocaine kinetics. Clin. Pharmacol. Ther. 27, 386-394 (1980).

3. Barnett, G., Hawks, R. \& Resnick, R. Cocaine pharmacokinetics in humans. J. Ethnopharmacol. 3, 353-366 (1981).

4. Chou, M. J., Ambre, J. J. \& Ruo, T. I. Kinetics of cocaine distribution, elimination, and chronotropic effects. Clin. Pharmacol. Ther. 38, 318-324 (1986).

5. Fattore, L. et al. Astroglial in vivo response to cocaine in mouse dentate gyrus: a quantitative and qualitative analysis by confocal microscopy. Neuroscience 110, 1-6 (2002)

6. Badisa, R. B. et al. N-acetyl cysteine mitigates the acute effects of cocaineinduced toxicity in astroglia-like cells. PLoS One 10, e0114285 (2015).

7. Guha, P., Harraza, M. M. \& Snyder, S. H. Cocaine elicits autophagic cytotoxicity via a nitric oxide-GAPDH signaling cascade. Proc. Natl Acad. Sci. USA 114, 1417-1422 (2016).

8. Arai, Y. et al. Inhibition of brain MAO-A and animal behaviour induced by phydroxyamphetamine. Brain Res. Bull. 27, 81-84 (1991).

9. Yu, R. C. et al. Characterization of cocaine elicited cell vacuolation: the involvement of calcium/calmodulin in organelle deregulation. J. Biomed. Sci. 15, 215-226 (2008). 
10. Ryan, L. J. et al. Cocaine, in contrast to d-amphetamine, does not cause axonal terminal degeneration in neostriatum an agranular frontal cortex of Long-Evans rats. Life Sci. 43, 1403-1409 (1988).

11. Yeh, S. Y. \& DeSouza, E. B. Lack of neurochemical evidence for neurotoxic effects of repeated cocaine administration in rats on brain monoamine neurons. Drug Alcohol Depend. 27, 41-61 (1991).

12. Little, K. Y. et al. Decreased brain dopamine cell numbers in human cocaine users. Psychiatry Res. 168, 173-180 (2009).

13. Zheng, F. \& Zhan, C. G. Modeling of pharmacokinetics of cocaine in human reveals the feasibility for development of enzyme therapies for drugs of abuse. PLoS Comput. Biol. 8, e1002610, https://doi.org/10.1371/journal.pcbi.1002610 (2012). PMID: 22844238.

14. Repetto, G. et al. Morphological, biochemical and molecular effects of cocaine on mouse neuroblastoma cells culture in vitro. Toxicol. Vitr. 11, 519-525 (1997).

15. Cunha-Oliveira, T. et al. Mitochondrial dysfunction and caspase activation in rat cortical neurons treated with cocaine or amphetamine. Brain Res. 1089, 44-54 (2006).

16. Cunha-Oliveira, T. et al. Differential cytotoxic responses of PC12 cells chronically exposed to psychostimulants or to hydrogen peroxide. Toxicology $\mathbf{2 1 7}$ 54-62 (2006).

17. Zhang, X. F., Hu, X. T. \& White, F. J. Whole-cell plasticity in cocaine withdrawal: reduced sodium currents in nucleus accumbens neurons. J. Neurosci. 18, 488-498 (1998).

18. O'Leary, M. E. \& Hancox, J. C. Role of voltage-gated sodium, potassium and calcium channels in the development of cocaine-associated cardiac arrhythmias. Br. J. Clin. Pharmacol. 69, 427-442 (2010).

19. Katyare, S. S., Bangur, C. S. \& Howland, J. L. Is respiratory activity in the brain mitochondria responsive to thyroid hormone action? A critical re evaluation. Biochem. J. 302, 857-860 (1994).

20. Liu, M. et al. Improved WATERGATE pulse sequences for solvent suppression in NMR spectroscopy. J. Magn. Reson. 132, 125-129 (1998).

21. Altieri, D. C. Survivin, versatile modulation of cell division and apoptosis in cancer. Oncogene 22, 8581-8589 (2003).

22. Yang, G. et al. Hydrogen sulfide protects against cellular senescence via Ssulfhydration of Keap1 and activation of Nif2. Antioxid. Redox Signal. 18, 1906-1919 (2013).

23. Baird, L. \& Dinkova-Kostova, A. T. The cytoprotective role of the Keap1-Nrf2 pathway. Arch. Toxicol. 85, 241-272 (2011).

24. Duong, $\mathrm{H}$. et al. Inhibition of NRF2 by PIK-75 augments sensitivity of pancreatic cancer cells to gemcitabine. Int. J. Oncol. 44, 959-969 (2014).

25. Evangelopoulos, M. E., Weis, J. \& Kruttgen, A. Signalling pathways leading to neuroblastoma differentiation after serum withdrawal:HDL blocks neuroblastoma differentiation by inhibition of EGFR. Oncogene 24, 3309e3318 (2005).

26. Marzinke, M. A. \& Clagett-Dame, M. The all-trans retinoic acid (atRA)-regulated gene Calmin (Clmn) regulates cell cycle exit and neurite outgrowth in murine neuroblastoma (Neuro2a) cells. Exp. Cell Res. 318, 85e93 (2012).

27. Oliveira, M. T., Rego, A. C., Morgadinho, M. T., Macedo, T. R. \& Oliveira, C. R. Toxic effects of opioid and stimulant drugs on undifferentiated PC12 cells. Ann. N. Y. Acad. Sci. 965, 487-496 (2002).

28. Cunha-Oliveira, T., Rego, A. C., Morgadinho, M. T., Macedo, T. \& Catarina Resende-Oliveira, C. T. Differential cytotoxic responses of PC12 cells chronically exposed to psychostimulants or to hydrogen peroxide. Toxicology $\mathbf{2 1 7}, 54-62$ (2006).

29. Yu, R. C. T. et al. Genetic toxicity of cocaine. Carcinogenesis 20, 1193-1199 (1999).

30. Lattanzio, F. A. et al. Cocaine increases intracellular calcium and reactive oxygen species, depolarizes mitochondria, and activates genes associated with heart failure and remodeling. Cardiovasc. Toxicol. 5, 377-389 (2005).

31. Kugelmass, A. D. et al. Activation of human platelets by cocaine. Circulation $\mathbf{8 8}$, 876-883 (1993)

32. Badisa, R. B., Batton, C. S., Mazzio, E., Grant, S. C. \& Goodman, C. B. Identification of biochemical and cytotoxic markers in cocaine treated PC12 cells. Sci. Rep. $\mathbf{8}$, 2710 (2018)

33. National Institute of Drug Abuse. Research Report Series (National Institute of Drug Abuse, Bethesda, MD, 2010).

34. Vitullo, J. C. et al. Cocaine-induced small vessel spasm in isolated rat hearts. Am. J. Pathol. 135, 85-91 (1989).

35. Welder, A. A. A primary culture system of adult rat heart cells for the evaluation of cocaine toxicity. Toxicology 72, 175-187 (1992).
36. Finol, $H$. J. et al. Hepatocyte ultrastructural alterations in cocaine users. J. Submicrosc. Cytol. Pathol. 32, 111-116 (2000).

37. Badisa, R. B., Darling-Reed, S. F. \& Goodman, C. B. Cocaine induces alterations in mitochondrial membrane potential and dual cell cycle arrest in rat C6 astroglioma cells. Neurochem. Res. 35, 288-297 (2010).

38. Nassogne, M., Evrard, P. \& Courtoy, P. J. Selective neuronal toxicity of cocaine in embryonic mouse brain cocultures. Proc. Natl Acad. Sci. USA 92, 11029-11033 (1995).

39. Nassogne, M. et al. Cocaine induces apoptosis in cortical neurons of fetal mice. J. Neurochem. 68, 2442-2450 (1997).

40. Lepsch, L. B., Planeta, C. S. \& Critoforo, S. C. Cocaine causes apoptotic death in rat mesencephalon and striatum primary cultures. Bio. Med. Res. Int. article ID 750752 (2015).

41. Módis, K. et al. Intramitochondrial hydrogen sulfide production by 3mercaptopyruvate sulfurtransferase maintains mitochondrial electron flow and supports cellular bioenergetics. FASEB J. 27, 601-611 (2013).

42. Jaiswal, A. K. Nrf2 signaling in coordinated activation of antioxidant gene expression. Free Radic. Biol. Med. 36, 1199-1207 (2004).

43. Kimura, Y. \& Kimura, H. Hydrogen sulfide protects neurons from oxidative stress. FASEB J. 18, 1165-1167 (2004).

44. Kumar, A., Singh, A. \& Ekavali. A review on Alzheimer's disease pathophysiology and its management: an update. Pharmacol. Rep. 67, 195-203 (2015).

45. Zhou, W. et al. Phenylbutyrate upregulates DJ-1 and protects neurons in cell culture and in animal models of Parkinson's disease. J. Biol. Chem. 286 14941-14951 (2011).

46. Badisa, R. B, Darling-Reed, S. \& Soliman, K. F. A. The protective role of Dglucose against 1-methyl-4-phenylpyridinium lon $\left(\mathrm{MPP}^{+}\right)$-induced mitochondrial dysfunction in C6 glial cells. Neurochem. Res. 35, 1413-1421 (2010).

47. Cao, H. et al. DNA demethylation upregulated nrf2 expression in alzheimer's disease cellular model. Front. Aging Neurosci. 7, 244 (2016).

48. Hardaway, C. M., Badisa, R. B. \& Soliman, K. F. A. Effect of ascorbic acid and hydrogen peroxide on mouse neuroblastoma cells. Mol. Med. Rep. 5, 1449-1452 (2012).

49. Zhang, L., Elmer, L. W. \& Little, K. Y. Expression and regulation of the human dopamine transporter in a neuronal cell line. Mol. Brain Res. 59, 66-73 (1998).

50. Furman, C. A. et al. Dopamine and amphetamine rapidly increase dopamine transporter trafficking to the surface: live-cell imaging using total internal reflection fluorescence microscopy. J. Neurosci. 29, 3328-3336 (2009).

51. Notter, M. F., Irwin, I., Langston, J. W. \& Gash, D. M. Neurotoxicity of MPTP and $\mathrm{MPP}^{+}$in vitro: characterization using specific cell lines. Brain Res. 456, 254-262 (1988).

52. Pappolla, M. A. et al. Melatonin prevents death of neuroblastoma cells exposed to the Alzheimer amyloid peptide. J. Neurosci. 17, 1683-1690 (1997).

53. Provost, P. Interpretation and applicability of microRNA data to the context of Alzheimer's and age-related diseases. Aging 2, 166-169 (2010).

54. Serrano, M. et al. Oncogenic ras provokes premature cell senescence associated with accumulation of $\mathrm{p}^{53}$ and p16 ${ }^{\text {INK4a }}$. Cell 88, 593-602 (1997).

55. Badisa, R. B. et al. Cytotoxic activities of some Greek Labiatae herbs. Phytother. Res. 17, 472-476 (2003).

56. Cover, T. L. et al. Effects of urease on HeLa cell vacuolation induced by Helicobacter pyroli cytotoxin. Infect. Immun. 59, 1264-1270 (1991).

57. Ikediobi, C. O. et al. Response of antioxidant enzymes and redox metabolites to cadmium-induced oxidative stress in CRL-1439 normal rat liver cells. Int. J. Mol. Med. 14, 87-92 (2004)

58. Denizot, R. \& Lang, R. Rapid colorimetric assay for cell growth and survival. J. Immunol. Methods 89, 271-277 (1986).

59. Zhu, Y. Z. et al. Hydrogen sulfide and its possible roles in myocardial ischemia in experimental rats. J. Appl. Physiol. 102, 261-268 (2007).

60. Bhuiyan, A. I. et al. Glutathione-garlic sulfur conjugates: slow hydrogen sulfide releasing agents for therapeutic applications. Molecules 20, 1731-1750 (2015).

61. Livak, K. J. \& Schmittgen, T. D. Analysis of relative gene expression data using real-time quantitative $P C R$ and the $2^{-\triangle \triangle}$ T method. Methods 25, 402-408 (2001).

62. Smith, I. K., Vierheller, T. L. \& Thorne, C. A. Assay of glutathione reductase in crude tissue homogenates using 5, 5'- dithiobis(2-nitrobenzoic acid). Anal. Biochem. 175, 408-413 (1988).

63. Aebi, H. Catalase in vitro. Met. Enzymol. 105, 121-126 (1984).

64. Yang, Y. et al. Role of glutathione S-transferases in protection against lipid peroxidation: over expression of hGSTA2-2 in K562 cells protects against hydrogen peroxide induced apoptosis and inhibits JNK and caspase 3 activation. J. Biol. Chem. 276, 19220-19230 (2001). 